\title{
PENGARUH CORPORATE GOVERNANCE, FINANCIAL INDICATORS, DAN UKURAN PERUSAHAAN TERHADAP FINANCIAL DISTRESS
}

\author{
Intan Nilasari \\ Universitas Sarjanawiyata Tamansiswa Yogyakarta \\ e-mail: Nilasariintan1@gmail.com
}

\begin{abstract}
This study aims to determine the effect of corporate governance, financial indicators, and company size on financial distress. Corporate governance in this study uses managerial ownership and institutional ownership indicators. For financial indicators using liquidity, leverage, and profitability. And the last one uses company size. The study took samples of manufacturing companies listed on the Indonesia Stock Exchange (BEI). The sampling method was non probability, and the sampling technique used purposive sampling. The data was collected using secondary data in the form of annual financial reports obtained from the official website of the Indonesia Stock Exchange, namely www.idx.co.id. The number of company lists that were processed was as many as 54 companies, and the number of samples that met the criteria for this study were 16 companies so that 80 observational data were obtained. The financial distress criteria in this study are measured using the interest coverage ratio. This study uses multiple linear regression as data analysis. The results of this study indicate that Managerial Ownership, Institutional Ownership, Liquidity, Leverage, Profitability, and Company Size have a significant influence on financial distress conditions. This study failed to prove the effect of managerial ownership, liquidity and profitability on the possibility of financial distress.
\end{abstract}

Keywords: Corporate Governance, Financial Indicators, Company Size, Financial Distress, Interest Coverage Ratio.

\section{PENDAHULUAN}

Suatu perusahaan yang penerapan tata kelolanya baik, maka dikatakan bahwa perusahaan tersebut akan terhindar dari permasalahan keuangan atau kebangkrutan yang biasa dikatakan dengan sebutan financial distress. dan sebaliknya, jika perusahaan dalam penerapan tata kelolanya kurang baik, maka perusahaan akan mengalami penurunan atau bahkan bisa mengalami kebangkrutan.

Likuiditas yang rendan dan perubahan signifikan dalam pengontrolan management dapat mengalami kondisi financial distress. Penyebab perusahaan mengalami financial distress atau kebangkrutan bisa disebabkan karena adanya faktor luar maupun dari dalam. Dengan menggunakan analisis rasio likuiditas, leverage, dan profitabilitas suatu manajer bisa mengetahui bahwa perusahaan mengalami kondisi kebangkrutan atau financial distress atau tidak. Dengan adanya faktor luar sehingga manajer dapat melihat corporate governance yang terdiri dari 2 elemen, yaitu kepemilikan manajerial \& kepemilikan institusional. Varibael financial indicators ini merupakan salah satu indikator untuk menganalisis adanya financial distress. Menggunakan rasio likuiditas, leverage, dan profitabilitas untuk memprediksi apakah perusahaan terjadi financial distress.

Untuk mengetahui seberapa layak atau seberapa besar kemampuan perusahaan untuk membayar hutang jangka pendeknya, manajer menggunakan rasio Likuiditas. Karena jika likuid semakin 
besar maka semakin mudah perusahaan untuk menutupi hutang jangka pendeknya. Perusahaan yang memiliki kinerja tata kelola yang tertata dengan baik, maka perusahaan dapat dikatakan terhindar dari kemungkinan terjadinya kebangkrutan.

Rasio pertama yaitu leverage. Dengan menggunakan rasio ini manajer dapat mengetahui hubungan antara kewajiban suatu perusahaan dengan total modal asset. Rasio selanjutnya adalah rasio profitabilitas. Dengan rasio ini manajer dapat mengetahui berapa besar keuntungan kas modal dari perusahaan. Karena kas modal yang besar dapat menentukan kondisi perusahaan yang baik. Selain rasio diatas, yaitu rasio likuiditas, rasio leverage dan rasio profitabilitas, ukuran perusahaan bisa memprediksi pengaruh financial distress. Manajer dapat mengetahui kapasitas perusahaan seberapa besar penjualan yang dihasilkan, Selain itu, dengan ukuran perusahaan manajer bisa mengetahui hasil penjualan suatu perusahaan. Jadi, semakin besar ukuran perusahaan dapat dikatakan bahwa perusahaan kemungkinan akan terhindar dari kebangkrutan atau financial distress.

Faktor lainnya yaitu corporate governance yang memiliki beberapa faktor seperti kepemilikan manajerial dan kepemilikan institusional. Corporate governance menggunakan principal-agent yang keduanya memiliki hubungan teori yaitu agency theory. Suatu konsekuensi yang mengakibatkan kepemilikan dan kontrol dengan pemegang sahan yang dimiliki dengan kepentingan manajer merupakan keberadaan principal-agent problem. Variabel corporate governane ini bisa dikatakan dapat menyembuhkan krisis ekonomi yang terjadi di Indonesia, karena corporate governance merupakan persyaratan yang baik dalm perusahaan. Dalam hal ini, corporate governance menggunakan elemen kepemilikan saham yang dimiliki manajerial dan kepemilikan saham yang dimiliki oleh pihak institusional. Jika saham manajerial dan institusional itu tinggi, hal itu dapat mendorong aktivitas monitoring yang dilakukan oleh perusahaan. Dalam suatu perusahaan jika terdapat kepemilikan manajerial dan kepemilikan institusional tentu akan ada pengawasan yang lebih ketat dan lebih baik tentunya pada manajemen dalam melaksanakan operasional perusahaannya. Hal itu akan membantu perusahaan terhindar dari terjadinya financial distress. Kepemilikan manajerial ini dapat mengurangi adanya permasalahan keagenan yang menyebabkan perusahaan mengalami kebangkrutan. Kepemilikan tersebut dapat meningkatkan kemampuan untuk mengurangi potensi kebangkrutan. Hal tersebut membuktikan jika perusahaan memiliki kepemilikan manajerial \& kepemilikan institusional terbukti bahwa dalam tata kelola pemegangan saham yang dimiliki akan terjaga dengan baik. Dalam menginvestasikan dananya, investor harus lebih jeli lagi karena itu merupakan hal yang penting dilakukan untuk memastikan apakah dana yng diinvestasikan itu aman atau tidak.

Dengan adanya argumen-argumen diatas, peneliti jadi lebih tertarik untuk meneliti tentang kebangkrutan (financial distress) dalam suatu perusahaan. Karena belum tentu jika perusahaan besar tidak mengalami financial distress atau kebangkrutan, maka penelitian ini bertujuan untuk melihat bagimana kinerja perusahaan manufaktur.

\section{KAJIAN PUSTAKA DAN PENGEMBANGAN HIPOTESIS Agency Theory}

Teori keagenan (agency theory) bertujuan untuk menjelaskan adanya pemisah kepentingan antara pemilik perusahaan dengan pengelolaan perusahaan. Pemisahan kepentingan ini dapat menimbulkan adanya konflik karena terdapat kontak yang diterapkan antara principal yang menggunakan agent untuk melaksanakan jasa. 
Dengan teori ini akan membahas adanya hubungan keagenan dimana suatu pihak tertentu mendelegasikan pekerjaan kepada pihak lain atau agent. Dimana pihak agent dan principal itu berupaya untuk memaksimalkan utilitasnya masing-masing sehingga dapat dikatakan bahwa manajemen tidak selalu bertindak sesuai dengan keinginin principal.

\section{Pengaruh Kepemilikan Manajerial terhadap Financial Distress}

Kepemilikan manajerial berperan untuk mengurangi masalah keagenan yang ada pada perusahaan yang apabila hal tersebut terjadi secara terus menerus akan menimbulkan kemungkinan .

Dengan hadirnya kepemilikan menajerial suatu perusahaan akan dapat mengatasi permasalahan keagenan manajer. Dengan hal ini perusahaan berharap adanya kepemilikan manajerial dapat mengatasi masalah yang terjadi dalam keagenan. Jika suatu perusahaan memiliki kinerja yang, maka tanggung jawab manajer dalam mengelola perusahaan akan lebih semakin besar.

Jika kepemilikan manajerial pada perusahaan semakin besar, akan terhindar dari kebangkrutan.

H1: Kepemilikan manajerial berpengaruh Negatif terhadap financial distress

\section{Pengaruh Kepemilikan Institusional terhadap Financial Distress}

Perusahaan yang memiliki kepemilikan institusional artinya perusahaan mampu mengindikasikan kemampuan monitor perusahaan (Emrinaldi, 2007). Kepemilikan institusional ini akan mencegah terjadi permasalahan antara pemilik dan manajer. Nilai kepentingan institusional suatu perusahaan dapat mencegah terjadinya terjadinya financial distress.

Berdasarkan peneliti Parulian (2007), adanya Investor institusional suatu perusahaan akan lebih mengawasi manajemen dalam melaksanakan operasi jika adanya kepemilikan institusional. Karena hal itu dapat mastikan kondisi perusahaan terkena financial distress.

H2: Kepemilikan Institusional berpengaruh Negatif terhadap financial distress

\section{Pengaruh Likuiditas terhadap Financial Distress}

Dalam rasio likuiditas terdapat perbandingan rasio lancar dengan angka 1:1 atau bisa dikatakan dalam persen (100\%) yang berarti aktiva lancar perusahaan dapat menutupi seluruh hutang lancarnya. Jika rasio likuiditas yang memiliki nilai banding diatas satu (1) dikatakan aman. Aktiva lancar suatu perusahaan harus diatas jumlah hutang lancar perusahaan karena suatu perusahaan membutuhkan pengeluaran biaya untuk memenuhi kewajiban lancarnya, perusahaan akan lebih siap untuk melunasi.

Peneliti Almilia(2003) menyatakan bahwa hasil current ratio berpengaruh negatif dan signifikan terhadap prediksii adanya financial distress pada suatu perusahaan. Pernyataan diatas membuktikan bahwa semakin besar kemampuan perusahaan untuk memenuhi kewajiban jangka pendeknya, maka semakin kecil kemungkinan perusahaan mengalami financial distress. pernyataan tersebut di dukung oleh penelitian yang dilakukan Jiming dan Wei Wei (2011)

H3: Likuiditas berpengaruh negatif terhadap financial distress

\section{Pengaruh Leverage terhadap Financial Distress}

Jika perusahaan memiliki tanggungan lain lebih banyak dari hutang dapat beresiko terjadinya kesulitan membayar tanggungan tersebut di masa yang akan datang.

Untuk mengukur kapasitas leverage menggunakan rasio hutang. Rasio hutang ini di hitung dengan membagikan jumlah total hutang dengan jumlah total asset. Adanya rasio leverage perusahaan akan mampu untuk mengukur besar aktiva perusahaan.

Jika leverage memiliki nilai koefisien negatif dan nilai rasionya tinggi 
maka perusahaan dapat terkena kondisi financial distress.

H4: Leverage berpengaruh Negatif Signifikan terhadap financial distress

\section{Pengaruh Profitabilitas terhadap Financial Distress}

Profitabilitas diukur dengan menggunakan ROA. Suatu perusahaan jika menghasilkan laba tinggi, berarti perusahaan akan semakin efektif jika penggunaan aktiva untuk menghasilkan laba atau keuntungan (Ardiyanto, 2011)

Semakin besar nilai ROA suatu perusahaan, seakin sedikit kemungkinan perusahaan mengalami kondisi financial distress.

Dan jika laba perusahaan semakin rendah maka kinerja keuangan yang kurang baik akan mengakibatkan penurunan profitabilitas, perusahaan rentan akan terkena financial distress.

H5: Profitabilitas berpengaruh negatif terhadap financial disstress

\section{Pengaruh Ukuran Perusahaan terhadap Financial Distress}

Ukuran perusahaan merupakan skala yang dapat menggambarkan keadaan perusahaan baik perusahaan kecil maupun perusahaan besar. Jumlah aset besar suatu perusahaan menunjukkan bahwa hubungan positif bagi kreditur, karena perusahaan lebih mudah untuk melunasi kewajiban di masa selanjutnya.

Hasil penelitian yang dilakukan oleh Robert (2017) menyatakan bahwa ukuran perusahaan berpengaruh positif signifikan terhadap financial distress. Penelitian tersebut sejalan dengan penelitian yang dilakukan oleh Puji (2015) HASIL PENELITIAN DAN PEMBAHASAN yang menyatakan bahwa ukuran perusahaan berpengaruh positif terhadap financial distress. Perusahaan dengan jumlah asset besar maka perusahaan dikatakan mampu memenuhi kewajiban yang jatuh tempo. Dengan demilikan, perusahaan yang memiliki asset besar kemungkinan tidak terkena kondisi kesulitan keuangan.

H6: Ukuran perusahaan berpengaruh positif terhadap financial distress

\section{METODE PENELITIAN \\ Populasi dan Sampel}

Peneliti menggunakan pendekatan penelitian kuantitatif dengan menggunakan populasi perusahaan dan teknik pengambilan sampel perusahaan dengan data sekunder dari situs resmi Bursa Efek Indonesia yaitu www.idx.id untuk mengumpulkan data serta menghasilkan kesimpulan. Populasi menggunakan perusahaan manufaktur Sektor Industri Barang Konsumsi yang terdaftar di Bursa Efek Indonesia (BEI) terdapat 54 populasi dengan periode 2015-2019. Berdasarkan kriteria, sampel yang memenuhi kriteria dari purposive sampling berjumlah 16 perusahaan.

\section{Analisis Regresi Linear Berganda}

Untuk mengetahui apakah variabel independen berpengaruh dengan financial distress, peneliti menggunakan analisis regresi.

Model regresi linear berganda penelitian yaitu:

$$
\begin{aligned}
& \mathrm{FD}=\mathrm{a}+b_{1} X_{1}+b_{2} X_{2}++b_{3} X_{3}+ \\
& b_{4} X_{4}+b_{5} X_{5}+b_{6} X_{6}+e
\end{aligned}
$$

Tabel 1. Analisis Statistik Deskripsi

\begin{tabular}{llccrc}
\hline & N & Minimum & Maksimum & Mean & Std. Deviation \\
\hline Financial Distress & 80 &, 15 &, 60 &, 50 &, 503 \\
Kepemilikan Manajerial & 80 &, 07 &, 63 &, 50 &, 719 \\
\hline
\end{tabular}




\begin{tabular}{lccccc}
\hline Kepemilikan Institusional & 80 &, 09 &, 79 &, 72 &, 774 \\
Likuiditas & 80 &, 12 & 2,37 & 2,24 & 1,599 \\
Leverage & 80 & 1,20 & 3,50 & 3,21 & 6,355 \\
Profitabilitas & 80 & 3,00 & 12,00 & 1,72 & 2,391 \\
Ukuran Perusahaan & 80 & 23,00 & 32,00 & 18,05 & 14,203 \\
Valid N (listwise) & 80 & & & & \\
\hline
\end{tabular}

Hasil analisis deskripsi berdasarkan tabel 1. Data yang digunakan dalam penelitian sebanyak 80 sempel $(\mathrm{N})$. Dapat dilihat bahwa rata-rata (mean) perusahaan tersebut hanya memenuhi $50 \%$ dan standar devisiasinya 50,3\%. Nilai financial distress tertinggi (maximum) sebesar 60\% sedangkan nilai financial distress terendah (minimum) sebesar 15\%. Variabel financial distress di perusahaan tersebut yang diukur menggunakan variabel dummy memiliki 16 sampel perusahaan dari 54 perusahaan manufaktur sektor industri barang konsumsi yang terdaftar di BEI.

Uji Deskripsi diatas menunjukkan bahwa kepemilikan manajerial memiliki nilai rata-rata 0,50 (50\%) dan nilai standar devisiasi memiliki nilai 0,719 (71,9\%). Analisis deskripsi diatas, nilai rata-rata Kepemilikan institusional $0,72(72 \%)$ dan nilai standard deviation memiliki nilai
0,774 $(77,4 \%)$. Hasil dari analisis deskripsi diatas menunjukkan bahwa nilai likuiditas dapat di hitung dengan membandingkan aktiva lancar dengan liabilitas lancar. Likuiditas dengan nilai mean 2,24 (2\%) dan nilai standard deviation 1,559 (1\%). Hasil dari uji deskripsi diatas bahwa leverage memiliki nilai rata-rata sebesar $3,21(3 \%)$ dan standard deviation 6,355 $(6 \%)$. Analisis deskripsi diatas nilai profitabilitas dapat di ukur dengan net profit dengan total assets. Nilai rata-rata Profitabilitas 1,72 (1\%) dan nilai standard deviation 2,391 (2\%). Hasil dari analisis deskripsi pada tabel 1. menunjukkan bahwa ukuran perusahaan dapat di ukur menggunakan rumus Ln(total asset). Ukuran perusahaan memiliki nilai rata-rata $18,05(18 \%)$ dan nilai standard deviation sebesar $\quad 14,203 \quad$ (14\%).

Tabel 2. Rangkuman Hasil Uji t

\begin{tabular}{lccc}
\hline \multicolumn{1}{c}{ Model } & T & Sig. & Collinearity Statistics \\
\cline { 4 - 4 } & & & Tolerance \\
\hline (Constant) & 5,295 &, 000 & \\
Kepemilikan Manajerial &, 211 &, 834 &, 944 \\
Kepemilikan Institusional & 3,304 &, 001 &, 907 \\
Likuiditas & $-4,308$ &, 000 &, 927 \\
Leverage & 2,933 &, 004 &, 849 \\
Profitabilitas & 1,154 &, 252 &, 939 \\
Ukuran Perusahaan & 2,053 &, 044 &, 887 \\
\hline
\end{tabular}

\section{Pengaruh Kepemilikan Manajerial Terhadap Financial Distress}

Hasil uji pertama (H1) kepemilikan manajerial manufaktur industri barang konsumsi nilai signifikan 0,834 dan t hitung
0,211. Nilai signifikan $0,834>0,05$. dengan nilai $\mathrm{t}$ hitung positif tetapi nilai signifikan lebih dari 0,05 berarti kepemilikan manajerial berpengaruh negatif terhadap kesulitan keuangan. 
Berdasarkan penelitian Sastriana dan Fusd(2013), Wardhani (2006), dan Parulina(2007) yang mengungkapkan kepemilikan manajerial tidak berpengaruh terhadap Financial Distress.

\section{Pengaruh Kepemilikan Institusional Terhadap Financial Distress}

Hasil uji kedua (H2), nilai t hitung 3,304 dan bertanda positif signifikan 0,001 dibawah < 0,05. Dapat diinterpretasikan kepemilikan institusional memiliki pengaruh positif terhadap kesulitan keuangan. Penelitian ini sejalan dengan penelitian Setiawan (2014) kepemilikan institusional memiliki pengaruh positif terhadap financial distress.

\section{Pengaruh Likuiditas Terhadap Financial Distress}

Hasil pengujian ketiga $(\mathrm{H} 3), \mathrm{t}$ hitung $-4,308$ bertanda negatif dengan nilai signifikan 0,000 dibawah $<0,05)$. Artinya, likuiditas berpengaruh negatif pada kesulitan keuangan. Penelitian ini didukung oleh peneliti almilia \& kristijadi(2003), fitdini(2009), jiming \& $\quad d u(2011)$ mengungkapkann likuiditas berpengaruh negatif terhadap kesulitan keuangan. Pernyataan tersebut mengungkapkan bahwa nilai rasio likuiditas semakin tinggi, maka perusahaan akan semakin aman dalam pengolahannya.

\section{Pengaruh Leverage Terhadap Financial Distress}

Perhitungan keempat (H4), diketahui nilai t hitung 2,933 dan bertanda positif nilai signifikan 0,004 dibawah < 0,05 . Artinya, leverage memiliki pengaruh positif signifikan terhadap financial distress perusahaan manufaktur sektor industri barang konsumsi periode 2015-2019. Penelitian ini di dukung dengan penelitian Fitdini (2009), Jiming \& Du (2011), dan Hanifah \& Agus (2013) mengungkapkan bahwa Leverage memiliki pengaruh positif terhadap financial distress.
Berdasarkan penejlasan di atas, dijelaskan jika tingkat hutang yang tinggi itu menyebabkan kewajiban perusahaan melunasi pokok pinjaman beserta bunganya. Sehingga pada saat waktu jangka panjangnya akan mengalami kesulitan keuangan perusahaan yang akan memicu terjadinya financial distress.

\section{Pengaruh Profitabilitas Terhadap Financial Distress \\ Perhitungan kelima (H5), nilai $t$} hitung 1,154 bertanda positif dengan signifikan 0,252 diatas 0,05. Karena nilai signifikan diatas 0,05 maka profitabilitas perusahaan memiliki rpengaruh negatif terhadap kesulitan keuangan. Penelitian ini sejalan dengan penelitian Alfinda Rohmadini(2018) yang mengungkapkan profitabilitas memiliki pengaruh negatif terhadap financial distress.

\section{Pengaruh Ukuran Perusahaan Terhadap Financial Distress}

Hasil Perhitungan keenam (H6), $\mathrm{t}$ hitung 2,053 bertanda positif signifikan sebesar 0,044 dibawah $<0,05$. Karena nilai signifikan dibawah 0,05 artinya Ukuran perusahaan memiliki pengaruh positif terhadap kesulitan keuangan (financial distress). Hasil pengujian tersebut didukung oleh penelitian Almilia \& Kristijadi(2003), Fitdini(2009), Jiming \& Du(2011) mengungkapkan ukuran perusahaan berpengaruh positif signifikan terhadap kesulitan keuangan.

\section{KESIMPULAN}

Setelah melakukan pengujian tentang "Pengaruh Corporate Governance, Financial Indicators, dan Ukuran Perusahaan terhadap Financial Distress pada Perusahaan Manufaktur Sektor Industri Barang Konsumsi periode 20152019" kesimpulannya yaitu, hasil pengujian hipotesis variabel X1 (Kepemilikan Manajerial) berpengaruh negatif terhadap financial distress pada perusahaan manufaktur sektor industri barang konsumsi 
yang terdaftar di Bursa Efek Indonesia Hasil uji hipotesis yang kedua secara persial bahwa variabel X2 (Kepemilikan Institusional) memiliki pengaruh dan signifikan terhadap financial distress. Pengujian hipotesis yang ketiga secara persial variabel X3 (Likuiditas) tidak berpengaruh signifikan terhadap financial distress. Hasil uji hipotesis yang keempat secara persial bahwa variabel Leverage (X4) memiliki pengaruh positif dan signifikan terhadap kondisi financial distress. Hasil uji hipotesis yang kelima secara persial bahwa variabel X5 (Profitabilitas) tidak berpengaruh signifikan terhadap financial distress. Hasil uji hipotesis terakhir variabel X6 (Ukuran Perusahaan) memiliki peengaruh positif dan signifikan terhadap financial distress.

Keterbatasan penelitian ini hanya menggunakan 80 sampel perusahaan manufaktur sektor industri barang konsumsi. Disarankan penelitian berikutnya untuk menggunakan variabel mekanisme corportae governance lengkap seperti komisarin independen, komite audit, dan variabel lain sebagainya yang mampu untuk menjadi faktor untuk memprediksi kesulitan keuangan. Dan disarankan untuk perusahaan agar lebih memperhatikan tata kelola perusahaannya tetap dalam kondisi yang baik dan terhindar dari kondisi kesulitan keuangan.

\section{DAFTAR PUSTAKA}

Abbas, D. S. (2019). Pengaruh Likuiditas, Komisaris Independen, Kepemilikan Institusional Dan Ukuran Perusahaan Terhadap Financial Distress (Pada Perusahaan Sektor Aneka Industri Yang Terdaftar Di Bursa Efek Indonesia Pada Periode 2013-2016). Jurnal Ilmiah Akuntansi Universitas Pamulang, 7(2), 119-127.

Https://Doi.Org/Http://Dx.Doi.Org/10.324 93/Jiaup.V7i2.2513

Abbas, D., Hakim, M. Z., \& Rustandi, R. (2019). Pengaruh Profitabilitas,
Solvabilitas, Opini Audit Dan Reputasi Kantor Akuntan Publik Terhadap Audit Report Lag (Pada Perusahaan Manufaktur Yang Terdaftar Di Bursa Efek Indonesia Pada tahun 2012-2015). Competitive, 3(1), 21-39.

https://doi.org/http://dx.doi.org/10.31000/ competitive.v3i1.1531

Bram Hadianto. 2008. "Pengaruh Struktur Aktiva, Ukuran Perusahaan, Dan Profitabilitas Terhadap Struktur Modal Emiten Sektor Telekomunikasi Periode 2000-2006: Sebuah Penguji Hipotesis Pecking Order". Jurnal Manajemen Maranatha. Vol 7. No 2. Pp 14-29

Cinantya, I., \& Merkusiwati, N. (2015). Pengaruh Corporate Governance, Financial Indicators, Dan Ukuran Perusahaan Pada Financial Distress. EJurnal Akuntansi, 10(3), 897-915.

Hanafi, Mamduh \& Halim, Abdul (2016) Analisis Laporan Keuangan edisi ke lima. Yogyakarta: UPPSTIM YKPN.

Hanifah, OE., Purwanto, A. (2013). Pengaruh Struktur Corporate Governance Dan Financial Indicators Terhadap Kondisi Financial Distress, Diponegoro Journal of Accounting, Volume. 2, Nomor. 2.

I Gusti Agung Ayu Pritha Cinantya dan Ni Ketut Lely Aryani Merkusiwati. 2015. "Pengaruh Corporate Governance, Financial Indicators, Dan Ukuran Perusahaan Pada Financial Distress". EJournal Akuntansi Universitas Udayana. Vol 10. No 3. Pp 897-915

Jensen, M. C., Meckling, W. H. (1976). Theory of the firm: managerial behavior, agency costs, and ownership structure. Journal of Financial Economics 3, 305-360.

Keuangan, P. R., Perusahaan, U., Inflasi, D. A. N., Financial, T., Di, D., \& Pertambangan, S. (2018). 2018. 6, 359-366.

Lee, T. S., Yeh, Y. H. (2004). Corporate governance anda financial distress: 
evidence from Taiwan. An international review 12(3), 378-388.

Ni Wayan Krisnayanti Arwinda Putri dan Ni Ketut Lely Aryani Merkusiwati. 2014. "Pengaruh Mekanisme Corporate Governance, Likuiditas, Leverage, Dan Ukuran Perusahaan Pada Financial Distress". E-Journal Akuntansi Universitas Udayana. Vol 7. No 1. Pp 93106

OECD Principles of corporate governance. 1999

Putri, KA., Merkusiwati, LA. (2014). Pengaruh Mekanisme Corporate Governance, Likuiditas, Leverage, Dan Ukuran Perusahaan Pada Financial Distress, EJurnal Akuntansi Universitas Udayana 7.1, Hlm 93-106.

Rinofah, R., Mujino. (2020). Pengaruh Arus Kas Dan Profitabilitas Terhadap Harga Saham Di Indonesia Dengan Financial Distress Sebagai Variabel Moderasi. Jurnal Akuntansi \& Manajemen Akmenika Vol. 17 No. 1 Tahun 2020

Salloum, C., \& Azoury, N. (2012). Corporate governance and firms in financial distress: Evidence from a Middle Eastern country. International Journal of Business Governance and Ethics, 7(1), 1-17. https://doi.org/10.1504/IJBGE.2012.0461

$\underline{02}$

Wulandari, D. V., Lengga, I., Munthe, S., \& Ruwanti, S. (2016). Pengaruh Corporate Governance Terhadap Peringkat Obligasi Pada Perusahaan Manufaktur yang Terdaftar di Bursa Efek Indonesia Periode 2013-2016. Lp3M Umrah, 60(2), 1-21 